\title{
E-learning During the Coronavirus Pandemic - Creating Educational Resources for Teaching Medical Students
}

\author{
Małgorzata Grześkowiak ${ }^{1}$, Izabela Chudzicka-Strugała ${ }^{2}$, \\ Barbara Zwoździak ${ }^{2}$, Ewelina Swora-Cwynar ${ }^{3}$, \\ Kacper Nijakowski ${ }^{4}$, Marta Jokiel ${ }^{5,6}$, Magdalena Roszak ${ }^{7}$
}

1 Department of Teaching Anaesthesiology and Intensive Therapy, Poznan University of Medical Sciences, Poland

2 Department of Medical Microbiology, Poznan University of Medical Sciences, Poland

3 Department of Gastroenterology, Dietetics and Internal Medicine, Poznan University of Medical Sciences, Poland

4 Department of Conservative Dentistry and Endodontics, Poznan University of Medical Sciences, Poland

5 Department of Physiotherapy, Poznan University of Medical Sciences, Poland

6 Traumatology, Orthopedics and Hand Surgery Department, Poznan University of Medical Sciences, Poland

7 Department of Computer Science and Statistics, Poznan University of Medical Sciences, Poland

\begin{abstract}
As a result of the epidemiological situation in Poland that occurred as a consequence of the SARS-CoV-2 pandemic, all classroom study was suspended in March 2020 and schools were required to deliver online education. There number of teachers who create educational resources for medical e-education, also those including interactive elements, is still insufficient. Teachers' IT skills must be continuously improved and they have to take part in e-learning course design training programmes, taking into account the characteristics of the teaching process in medical sciences and health studies. The existing examples of effective e-classes, particularly for medical training, are important sources of knowledge on how to build e-learning courses for beginners and an inspiration for others in subsequent implementations. This knowledge is needed immediately, and the time available for acquiring it is shorter than previously, as the epidemic does not allow for full-range training schemes. This paper presents such results, collected from the period from March to June 2020 at the Poznan University of Medical Sciences by teachers who had started working on e-learning resources in 2019 and are successfully implementing these in the educational offer made available to their students as part of various curricula.
\end{abstract}




\section{Introduction}

As a result of the epidemiological situation in Poland that occurred as a consequence of the SARS-CoV-2 pandemic, all classroom study was suspended in March 2020 and schools were required to deliver online education. It posed a major challenge for every university, but specifically for medical schools, which had to switch immediately to an e-learning-only system while maintaining the highest standards in terms of teaching and contents. The academic year 2020/21 will also be based on distance education, which is now the foundation of all education, with the use of e-learning technologies, virtual reality, and Internet communication.

Medical universities in Poland had been offering e-learning classes before, which are now becoming a standard for some courses, yet only few of them were subjects taught exclusively online. Due to its unique features, medical training is mainly offered as a blended-learning model, where part of the education takes place in classrooms and the rest proceeds online, with the use of an e-learning portal (Boczkowska et al., 2018; Kononowicz et al., 2020; Kołodziejczak \& Roszak, 2017; Roszak, 2019).

IT departments or e-learning centers exist at medical universities that employ professionals with an appropriate e-education level and offer competence-building educational materials. Universities have the requisite IT infrastructure and cooperate with recording studios. This scale of operation, however, is not as large as in the case of technical universities or universities offering science courses. There are not yet enough teachers who create educational resources for medical e-education, including those with interactive elements. Teachers' IT skills must be continuously improved and they have to take part in e-learning course design training programmes, taking into account the characteristics of the teaching process in medical sciences and health studies (Ren-Kurc et al., 2012; Roszak et al., 2019).

The unusual period, i.e. the state of epidemic we are still experiencing, has been a strong stimulus for teachers' readiness to improve their teaching qualifications and an openness to share their experiences in the field of projects focused on the implementation of e-learning. Examples of effective e-classes, particularly in the area of medical training, are important sources of knowledge on how to build e-learning courses for beginners and an inspiration for others in subsequent implementations. This knowledge is needed immediately, and the time available for acquiring it is shorter than previously, as the epidemic does not allow for full-range training schemes. The existing techniques and scenarios can offer support to teachers and fill the gaps, particularly with respect to building electronic educational 
resources or course development for clinical training, which used to take part in classrooms only. The quality of e-learning sessions largely depends on the educational resources incorporated in the courses, which should include interactive components, extending the knowledge recipient's memory trace (Leszczyński et al., 2017; Roszak, 2019). This paper presents such results, collected in the period from March to June 2020 at the Poznan University of Medical Sciences by teachers who had started working on e-learning resources in 2019, after completing an online course design training, and were successfully implementing these in the educational offer made available to their students as part of various curricula.

Phrases encountered in literature such as e-education, distance learning, distance education, e-learning, etc. represent the same education process, with the exception of certain key functions. In this paper, such phrases are used interchangeably.

\section{The Beginnings - Behavior Standards and the Environment, Based on the Example of PUMS}

The implementation of e-learning courses and the building of course and electronic resources is frequently a cause for concern and anxiety for the teachers, concerning teaching tools and methods previously unknown to them. Participation in trainings is necessary to overcome such barriers; it should be provided on a regular basis, with a special emphasis on the improvement of IT competences. After completing the course, each trainee has acquired the theoretical background and the practical ICT skills to commence such work. The essential aspects include the knowledge providers' (content authors') intentions and enthusiasm for work, whereas the university infrastructure and the units supporting the development of e-education should assist them with these tasks. During the initial phase, particularly during the process of designing the first courses and first learning resources, institutional backup is always essential, affecting these teachers' future activity (Roszak \& Kołodziejczak, 2017).

The Poznan University of Medical Sciences (PUMS) teaches approximately 7000 students; PUMS is among the leading and largest medical schools in Poland, and at the same time an example of a non-technical school. At the time the epidemic broke out, the university had the following applications in place and made it available to teachers: a virtual student service system (WISUS), consisting of an academic student-teacher communicator with a knowledge repository, MS Teams, and an e-learning portal (sOLAT). Certain units operating within the university structure are 
responsible for supporting the design and execution of e-learning courses, including the on-site examination center and the newly established on-site recording studio. It is therefore a typical environment needed for pursuing e-education, available for universities in Poland. The ranges or sizes of their activities may vary, yet the component parts are very similar. The pandemic caused an increase in the volume of tasks and work carried out with the participation of such units. The volume of electronic education resources began to increase as well, which will help the implementation of further complete e-learning courses at a broader scale than before.

Teaching an e-learning class, e.g. an online lecture, differs greatly from a direct meeting with students in a lecture hall or a practice classroom. If a learning material (such as an educational video) was prepared by a teacher for the first time and is covered by students individually, there is no feedback available on its reception or understanding. In fact, this is the top priority aspect, as PUMS teachers would frequently emphasize. Our constantly changing living and working environments requires university teachers to work out alternative methods for conveying knowledge to students at the faculties of medicine, medicine and dentistry, nursing, or biotechnology.

As of the beginning of the academic year 2019/20 (before the pandemic), to many medical school teachers, online teaching seemed to be a distant alternative, conceived only as a supplement of the existing forms of education. Today, with the SARS-CoV-2 pandemic, it has become a necessity. The PUMS teachers who accepted the challenge and took part in the internal training course on the Use of education platform for e-learning course design and felt encouraged to act afterwards by the people in charge of the implementation of e-education, boldly confirm today that in their case the process of creating and implementing e-learning courses went quite smoothly.

Medical university teachers believe that in a world where digitization starts to impact every aspect of our lives, it is high time that the most advanced solutions aimed at the progress of sciences were used. It can be a rough, winding patch, as the recent months have shown, requiring both the students and teachers to face new challenges. It is the teacher's duty to assist the students who, despite the initial euphoria they might have felt about their classes being canceled, found themselves equally lost in the situation. The extraordinary growth of technology has never before been appreciated as much as it is now, in the shadow of COVID-19, offering us communication options wherever we are at any given moment.

At some schools, teachers with the basic knowledge of e-learning and ICT competences, but without any experience with e-learning, undertook 
certain steps immediately to set up an online teaching system. On the basis of earlier cooperation with e-learning coordinators, new e-courses were developed on the sOLAT portal as early as on Friday, March 13, 2020, which were subsequently systematically extended with newly-designed education materials.

Below are practical examples of online courses and education resources for the distance education of medical students, developed on PUMS and used as an important part of the teaching process during the pandemic. They were rated highly by the knowledge recipients (students) after the end of the academic year 2019/20. The students accepted the learning process developed in its online form, while the teachers are continuing their work on building more educational resources for their courses, scheduled for implementation in the subsequent academic year 2020/21.

\section{Distance Learning in Courses in Conservative Dentistry and Endodontics}

The entire structure of the e-learning activities developed as part of the subject Conservative Dentistry and Endodontics for year 4 students at the Faculty of Medicine-Dentistry, is based on clinical cases. The following solutions were used for this purpose: 1) sOLAT as the university's e-learning portal; 2) MS Teams for synchronous (real-time) communication; and 3) Web 2.0 tool.

1) The e-learning course (Roszak et al., 2015), consisted of the following components (Figure 1):

a) Forum and notifications for asynchronous communication - delivery of organizational messages, including daily work schedules, course pass requirements, etc.;

b) Educational materials including seminar presentations for refresher purposes and additional materials, i.e. instruction videos or guidelines needed for the covered areas;

c) Project task (open-end questions) - students worked on tasks related to clinical cases in endodontics; teachers were evaluating them by sending individual comments about the completed tasks (feedback was essential);

d) Practice test for a self-check in diagnostics/therapy, with true/false questions (closed end questions);

e) Ask a teacher - an interface for quick individual student-teacher communication. 
Małgorzata Grześkowiak et al.

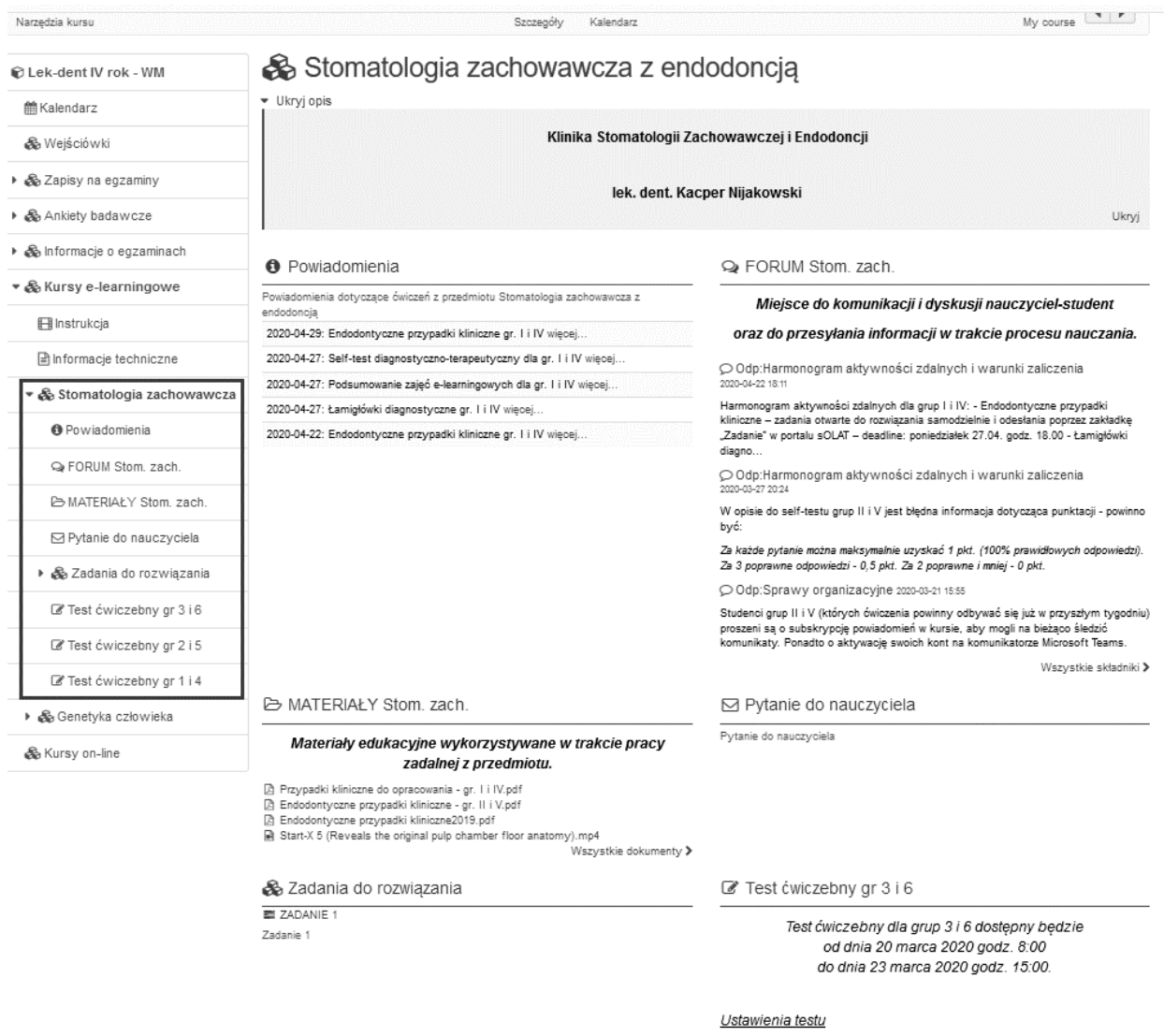

Figure 1. E-learning course in Conservative Dentistry and Endodontics for year 4 students of Medical-Dentistry

2) Kahoot/Socrative application - for diagnostic quizzes based on intraoral and radiological images (Maciejowska et al., 2019; Mokwa-Tarnowska, 2017).

3) Microsoft Teams communicator tool - for summing up a completed online study session and discussion of all the preceding tasks.

Teachers and dentists successfully met the challenges of the new reality, which is confirmed by the positive feedback from students whose on-site training programmes at clinics were suddenly interrupted by the epidemic. Below are some examples of such feedback, which constituted an important message for the teachers, to the effect that the proposed class methodology had been a success and met with the learners' acceptance:

- "When classroom meetings ended, the materials were made available very soon afterwards and the communication was good, we all knew what 
to do and what the deadline was, it was all transparent and therefore satisfying. I also believe that the criteria we had to fulfill to pass a course were fair."

- "Diversified activities (cases, test, quiz, consultation) with a clear feedback and a detailed, step-by-step discussion of any unclear items."

- "Specific tasks handed out for completion - good motivation for studying; Course summary test; Discussion of all the covered topics; Teacher available in case of any questions."

- "Discussion of complex clinical cases + discussion of the completed test.

We had the opportunity to understand our own mistakes exactly."

- "Commitment, friendly attitude, offering useful materials".

The only aspect to which the students had objections was the time pressure during online testing, as the university recommendation was to set 40-45 seconds per question.

\section{SONDA TV Show as an Inspiration for the Design of E-learning Lectures in Medical Microbiology}

Among the lectures delivered at a medical university in direct contact with students, there are meetings with very high levels of attendance, while others are less popular, attended by e.g. $20 \%$ students. As usual, much depends in such cases on the manner in which knowledge is conveyed, but also on the lecturers themselves and on the students' attitudes. During an e-learning session, without any direct contact with students, student interaction is limited. External factors also contribute to the fact that keeping the students alert at an e-class is a serious challenge for lecturers. Naturally, the primary goal for teachers is to achieve their teaching objectives and to cover the specific syllabus contents, yet it is also important to address the knowledge recipients' present needs in an optimized way, by preparing the educational resources according to their actual knowledge levels and stages of education. Sometimes the fixed framework of traditional lecture hours, together with a huge amount of other courses and issues faced by young people, can be a real inconvenience. Hence, fewer students may be present at traditional lectures. But in the case of elearning meetings, students have the opportunity to choose a convenient, more flexible time and place for studying, and to listen to the same lecture more than once. With more attention, they may be able to notice certain matters which could perhaps be used in their professional practice in the near future. 


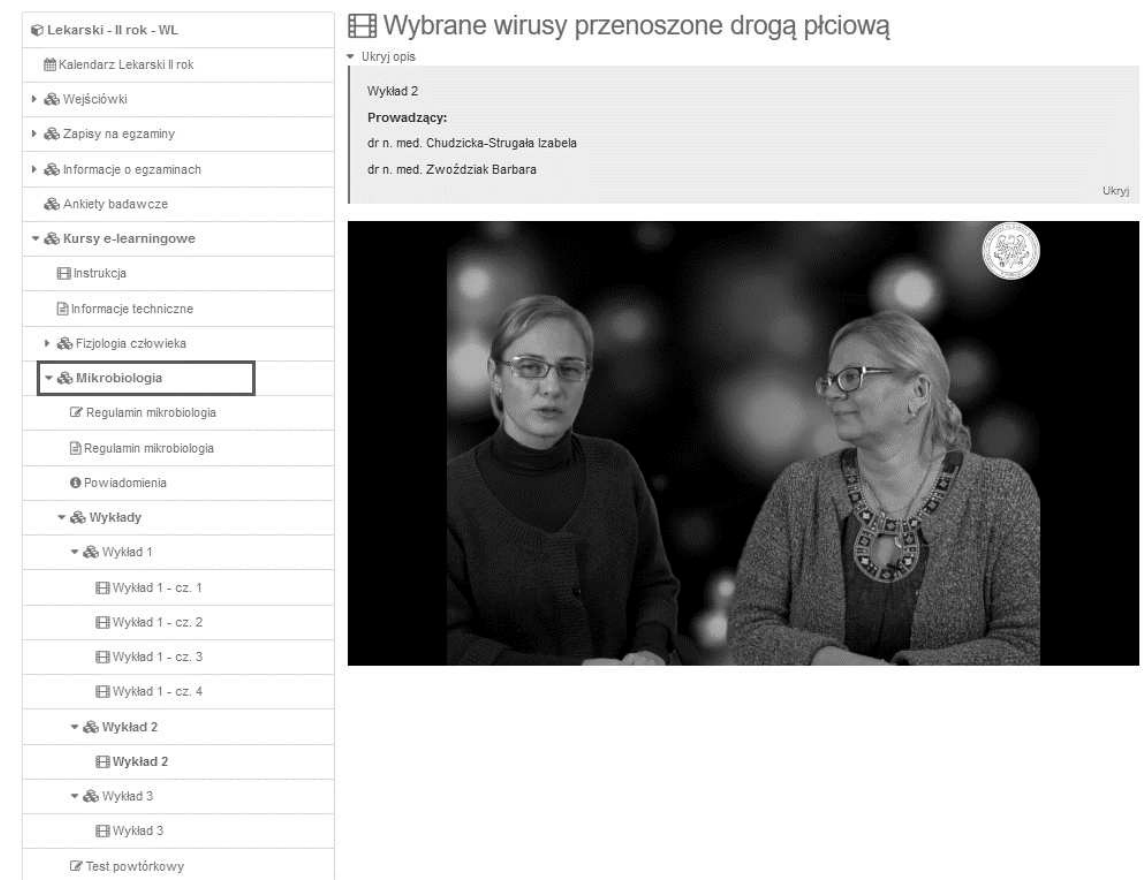

Figure 2. E-learning course in Medical Microbiology for year 2 students of Medicine

By reviewing the distance teaching methods applied at other e-courses in various fields of specialization, microbiology teachers developed their own knowledge transmission model for e-lectures. They set up a two-member team to jointly create multimedia-enhanced lectures, on a complementary basis - during the phases of lecture content development and recording. In this set-up, what one person says is supplemented by the other, offering a comprehensive set of knowledge on the subject. The model that was followed here was based on the Polish TV show called "SONDA", which provided the concept for preparing lectures on the subject (Figure 2). Was this approach accepted by the course audience, i.e. the students at the faculty of Medicine? Their opinions, collected as early as during the course, confirmed that they were satisfied with this idea of lecture preparation. What mattered most for the teachers was that the students realized how important microbiology was for them, no longer considering it as nothing but yet another pass required during their course of study.

When preparing the educational resources, teachers paid special attention to presenting the topics in a way that would not only be interesting but also focused on their usefulness in a doctor's practice. Close collaboration 
between the knowledge providers in the process of preparation of contents for such resources was important here, so as to accomplish the most comprehensive presentation of the topic. The primary goal was to emphasize how this textbook/scientific area translates into the practical aspect.

Using the "SONDA" TV show as a model (airing in the 1980s, featuring Zdzisław Kamiński and Andrzej Kurek), the microbiology lectures were developed as a question-answer exchange, based on the clinical cases and expert knowledge of an experienced doctor and a biologist with extensive experience in the field of microbiology. The intention was to give the students the broadest possible outlook on the discussed cases on the basis of the problems mentioned. They were expected to help students become accustomed to listening and to asking the right questions, so as to direct the future doctors towards the right diagnosis and treatment. The method used during the course was aimed at making the students verify all the possible solutions. The "House M.D." TV show from the United States is a great example illustrating the effects of the implementation of this model. The main character's curiosity, with the added value of his assistants' knowledge, lets him solve even the most complex medical riddles. In this way, the microbiology teachers decided to engage their audience in interaction, to increase their engagement level, and at the same time to make use of their pre-existing knowledge acquired during earlier classes.

Engineering and technological innovations, so fascinating for today's 'generation Z' students, help teachers convey their knowledge in the described manner. Conventional teaching methods are often perceived as obsolete by young people, including medical university students, who acquire knowledge much less effectively than with the use of advanced contemporary educational solutions. E-learning enables the involvement of advanced video and audio recording techniques. The microbiology lectures, recorded together by the two-member teams at the school's studio, were a great success. Students return to them to reinforce and preserve their newly acquired knowledge. The lectures are revised in practical tests prepared on the basis of clinical cases, done by students as close-ended questions via an interactive question interface.

Due to the fact that the teachers consider these activities highly rewarding, they keep working on their toolbox (as a 'super duo'), intending to build even more interesting resources and friendly ways of conveying knowledge in the field of microbiology. They are continuing their work on further e-lectures because they believe their work will bring real results a new generation of well-educated healthcare professionals, full of passion and energy. 
Małgorzata Grześkowiak et al.

The teachers' attitude and the example of their work methodology used with the subject in question can inspire others to deliver e-learning lectures in a similar manner, on the basis of teachers' cooperation at all stages of the development of educational resources.

\section{The World of Gastroenterology Online - Interaction and Interactive Elements}

Gastroenterology teachers experienced a spectacular success in the new reality as they pursued the course syllabus with undeniable passion. In September 2019, the Gastroenterology, Dietetics and Internal Medicine Department and Clinic started working on implementing an e-learning scheme in lectures for year 5 students of Medicine. The first lecture was prepared by the Head of the Clinic, encouraging the other teachers to proceed with building more e-resources on the topic.

The interaction and interactive components of e-learning are of particular note, as their effect is that new knowledge remains for longer in the students' memory (Sobolewska \& Pinet-Peralta, 2019). Interactive elements constitute an important portion of educational materials, with a significant impact on the processes of memorizing. Two concepts should be emphasized here, which are usually considered identical: 1 . The interaction component: responding passively to user's action, 2 . The interactive component: generating a dynamic reaction. A test giving the student feedback on whether the answer is correct or not after every question is an example of an interaction component. However, a test in which the learner receives a summary result after finishing, together with comments, is an example of an interactive component.

In addition to the standard multimedia lecturing techniques, the gastroenterology teachers also introduced interactive tasks for students. These were added to the lectures as contents from the learning materials covered during the lecture entered into diagrams or tables, and a real-life case image gallery as a source of diagnostic imaging (Figure 3).

Self-tests were also developed for students to work with on their own, and recommended after each lecture as a way to verify the students' knowledge and to refresh the material. Their interactive character came from the fact that when a student was answering a question, they could use a tip/hint to lead them towards the correct answer (Figure 4, 5,6). With such a test, the learning process can be adjusted to every course participant's individual pace and ability, while at the same time showing the learner which topics 


\section{Jakie są przeciwwskazania do wykonania endoskopii?}

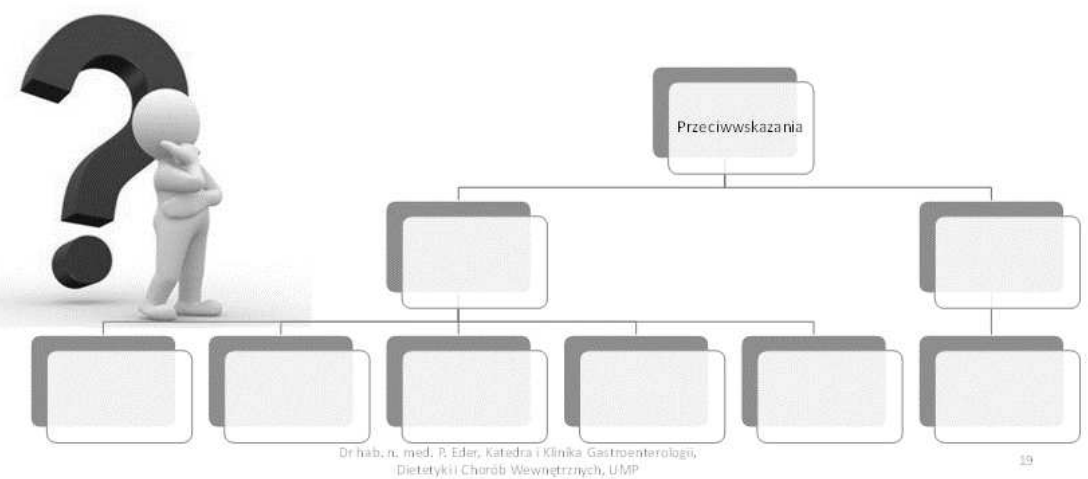

Figure 3. Questions during an e-learning lecture in Gastroenterology for year 5 students of Medicine

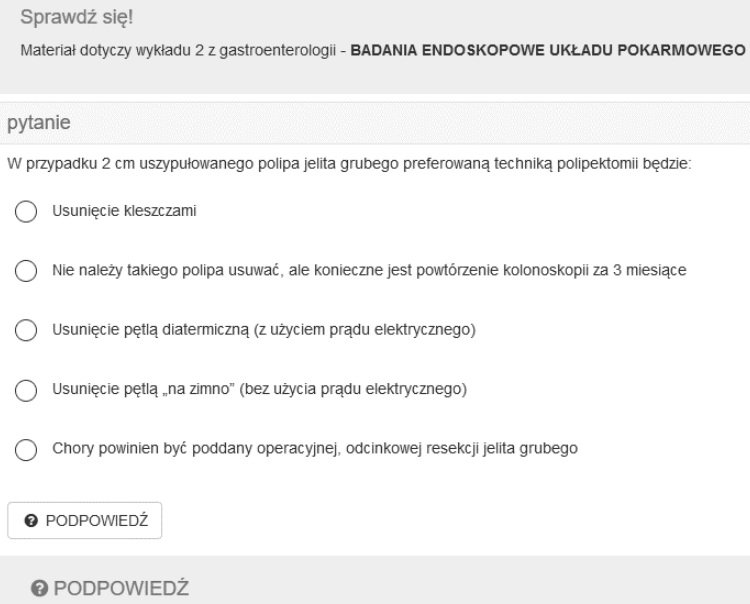

Metodẹ polipektomii powinniśmy dostosować głównie do morfologii usuwanej zmiany. Do usunięcia dużego uszypułowanego polipa jelita grubego konieczne jest zastosowanie akcesoriów umożiwiających radykalną resekcję przy tak rozległych zmianach przy jednoczesnym zachowaniu maksymalnego bezpieczeństwa (minimalizacja ryzyka krwawienia po polipektomii z zastosowaniem koagulacji)

Figure 4. Self-test question as a follow-up to an e-learning lecture in Gastroenterology for year 5 students of Medicine, with an example teacher's hint given before answering

still need to be worked on. The students were allowed to complete the test without any limitation, save that each student had to give at least $80 \%$ right answers at least once.

In their feedback, the students who attended the e-learning lectures in question emphasized the following aspects: flexibility of study time; ability 
Małgorzata Grześkowiak et al.

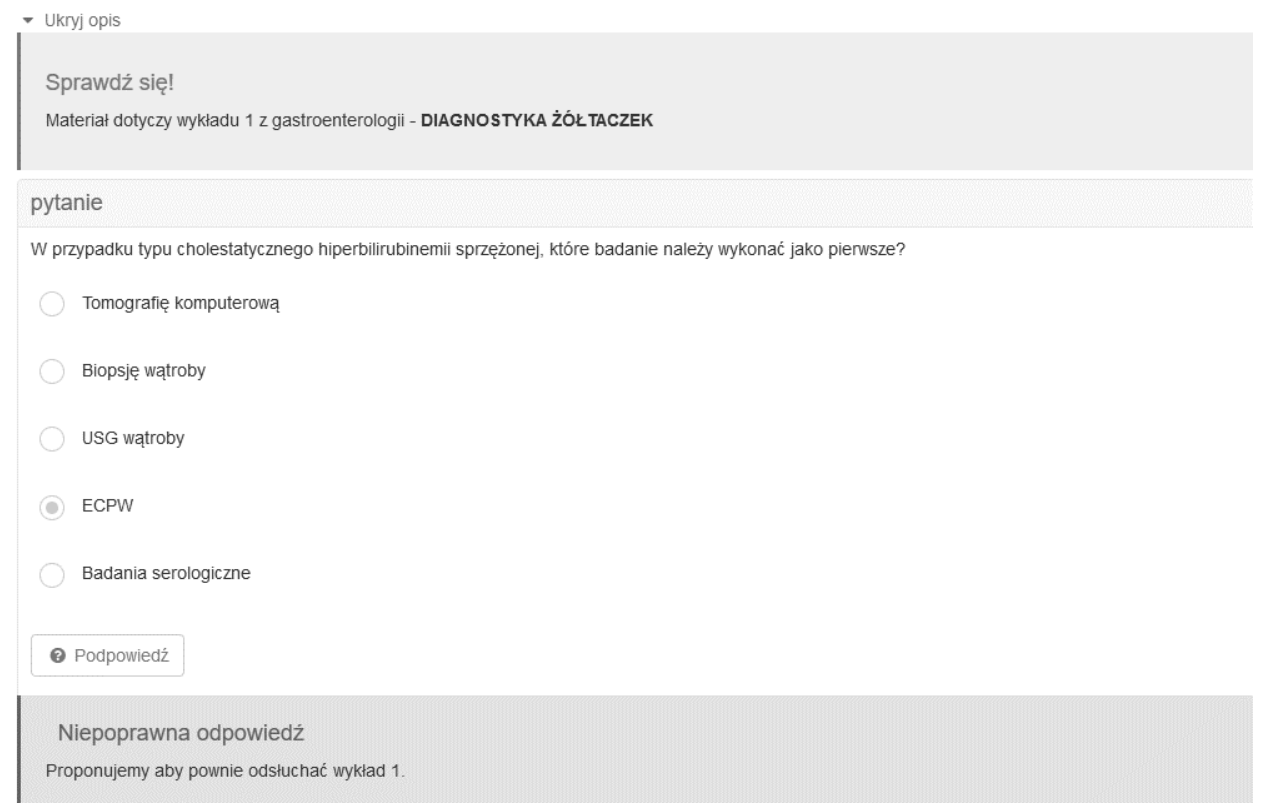

Figure 5. Self-test question as a follow-up to an e-learning lecture in Gastroenterology for year 5 students of Medicine, with an example reaction to a wrong answer

to return to a specified learning material many times; message accuracy; interactive character; lecturer availability, i.e. the available options for asking questions: on a forum or via an individual contact form in the course.

The teachers began their work on the e-learning resources in 2019 as a group consisting of 3 members, of whom one had completed a university training in distance learning and accepted the role of the coordinator of the whole team's work on the development of resources and courses. With the support from the department's head in the field of implementation of e-learning in gastroenterology and owing to his participation in the development of the first lecture, now (in 2020) the team of teachers involved in working on e-learning courses is composed of 13 members. The training programme was completed by another individual, who is now able to offer professional backup to other colleagues. It should be added that the gastroenterology staff are teachers and practicing doctors, working at a clinical hospital, whose efforts are focused on modernization and adaptation of more and more syllabus contents to the continuously growing World of Online Gastroenterology. The students' current status and their grades reinforce the staff's strong belief that online teaching i worth investing in. 


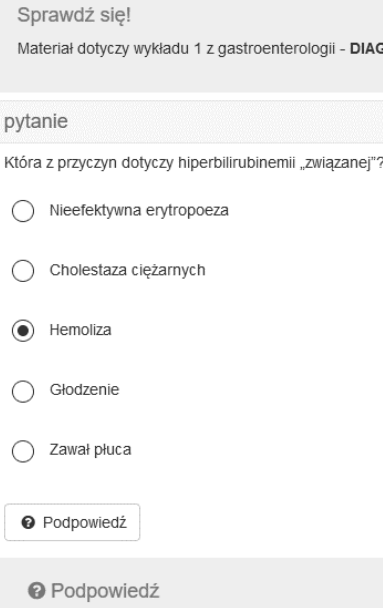

Figure 6. Self-test question as a follow-up to an e-learning lecture in Gastroenterology for year 5 students of Medicine, with an example teacher's hint

\section{Interactivity - AFTER or DURING a Lecture Involving a Live Demonstration?}

Teachers from the Department of Teaching Anaesthesiology and Intensive Therapy started creating resources for e-learning purposes immediately after the course in this field had been completed. Work started promptly, and the transition from traditional to e-learning meetings was scheduled in two fields of study.

The starting point were lectures and seminars for students of Medicine and Medicine and Dentistry at two faculties. E-learning courses for year 1 and year 2 students were successfully developed for such subjects as First Aid and Cardiocerebral Resuscitation with Simulation Elements; thus, improved teaching quality was delivered to students even before the pandemic started (Figure 7).

Recording video and audio pieces at the university's studio for predeveloped materials was perceived by the teachers as a very pleasant experience. An important element of e-learning courses are refreshers and self-check questions for topics covered by students during their individual course of study, to enable them to verify their knowledge on an ongoing 
Małgorzata Grześkowiak et al.

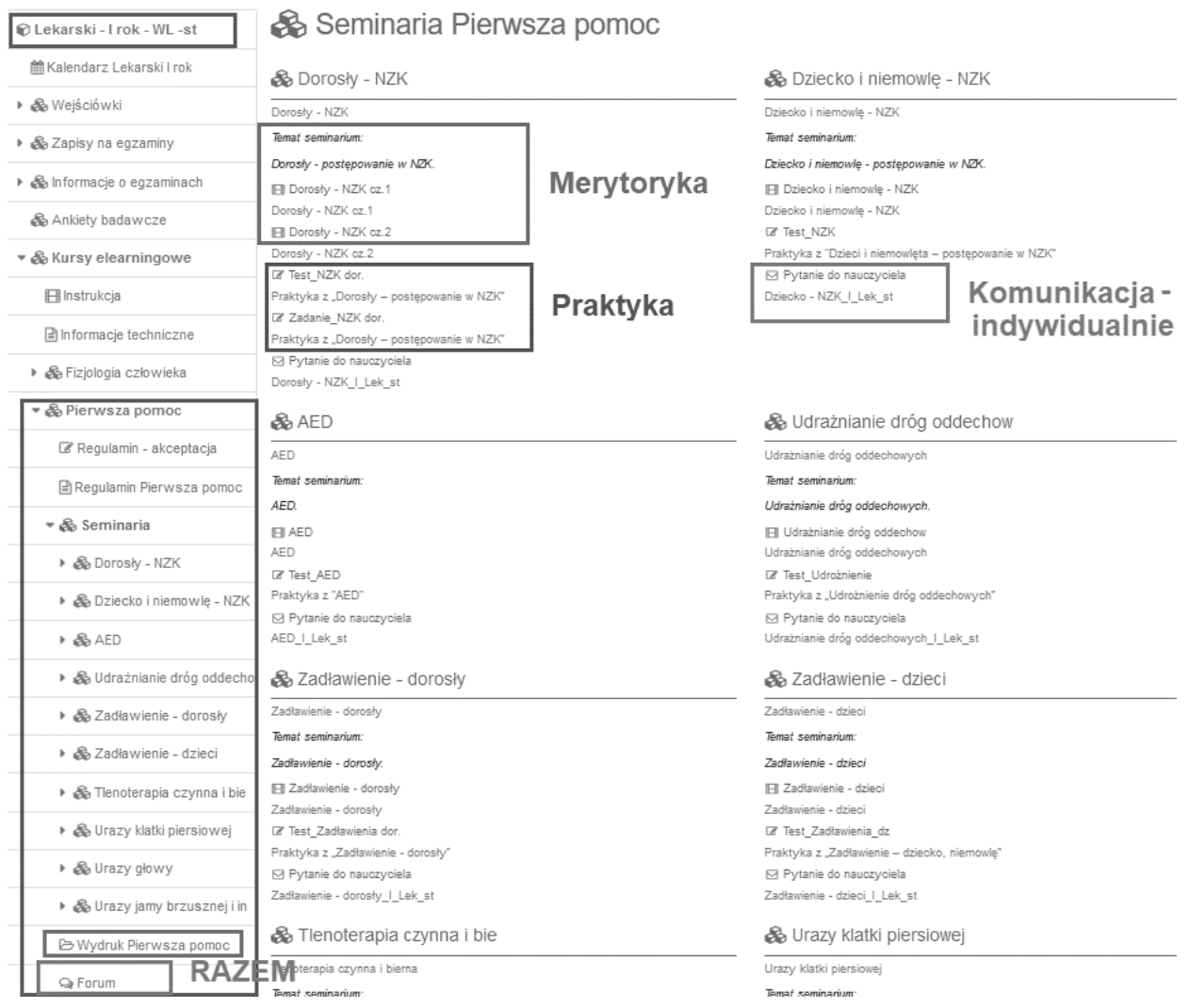

Figure 7. E-learning course in First Aid for year 1 students of Medicine. Example practical tasks in an e-learning course

basis. In content-related materials, teachers used two approaches. The first one consists in practice tests at the end of the presentation, with multiplechoice questions chosen randomly for students from a larger question base, with test questions and answer variants in a random order. For certain selected problems, questions were also prepared in a task format, to provide an even better stimulation for students' activity (Figure 8, 9). Another approach is to intertwine the presented lecture or seminar contents with questions as they are covered by the student. Without giving a correct answer, the student cannot proceed - the question is a pre-selected one, identical for every learner. Every approach has its advantages, and their impact on the effectiveness of the students' learning process is verified as part of the process of evaluation of teaching and knowledge (Mokwa-Tarnowska et al., 2018). 
E-learning During the Coronavirus Pandemic - Creating Educational...

Sprawdż się!

Materiał dotyczy zajęć e-learningowych prowadzonych przez Zakład Dydaktyki Anestezjologii i Intensywnej Terapii z „Dorosły - postępowanie w NZK”

Definicja

Wskaż definicję dorosłego / dziecka / niemowlęcia w aspekcie prowadzenia resuscytacji

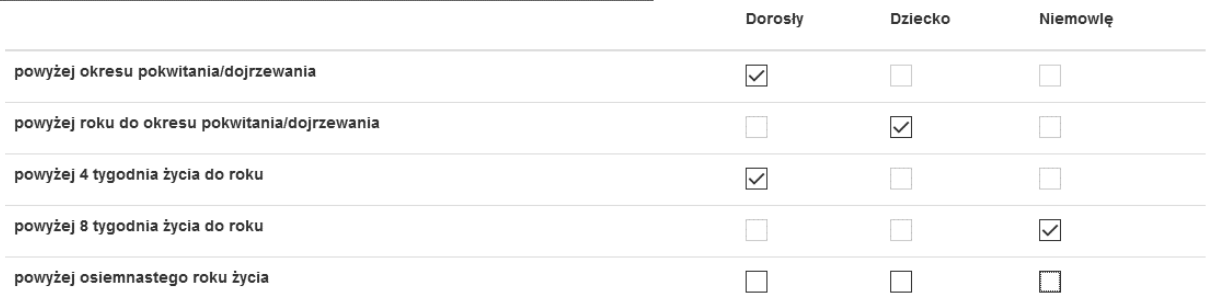

Figure 8. E-learning course in First Aid for year 1 students of Medicine. Example practical tasks in an e-learning course

Sprawdź się!

Materiał dotyczy zajęć e-learningowych prowadzonych przez Zakład Dydaktyki Anestezjologii i Intensywnej Terapii z „Dorosły - postępowanie w NZK”

Elementy

Wskaż elementy punktu A, B i C u dorosłeg:

Przeciagnij je z pierwszej kolumny do odpowiednich niebieskich pól
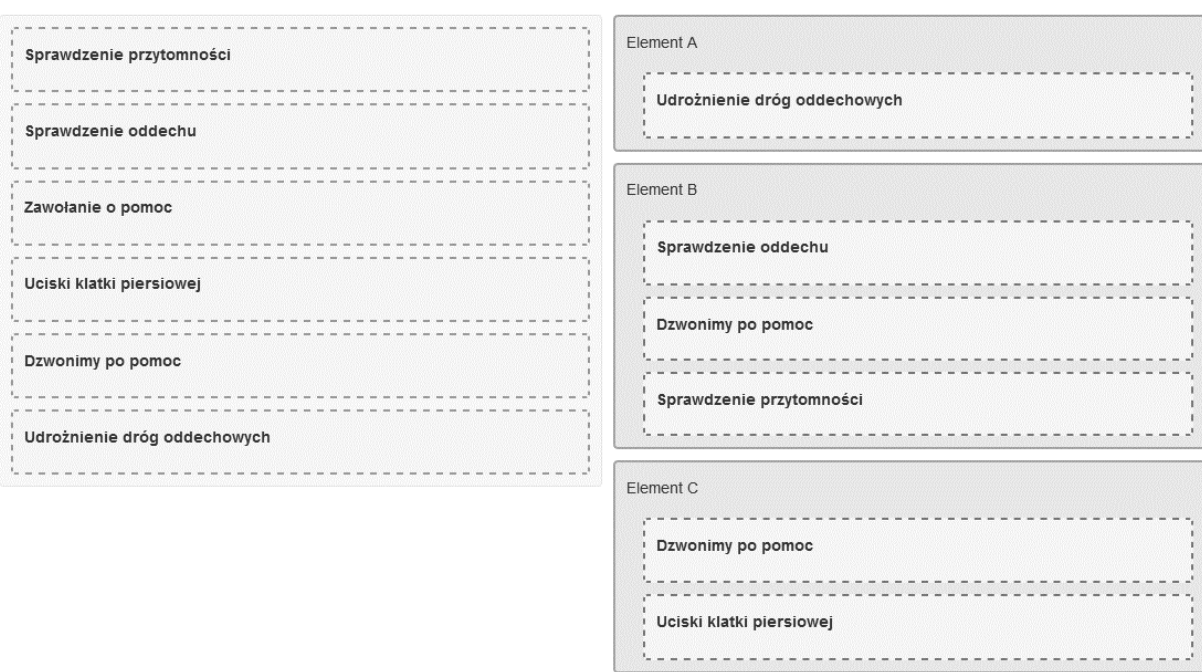

Figure 9. E-learning course in First Aid for year 1 students of Medicine. Example practical tasks in an e-learning course 


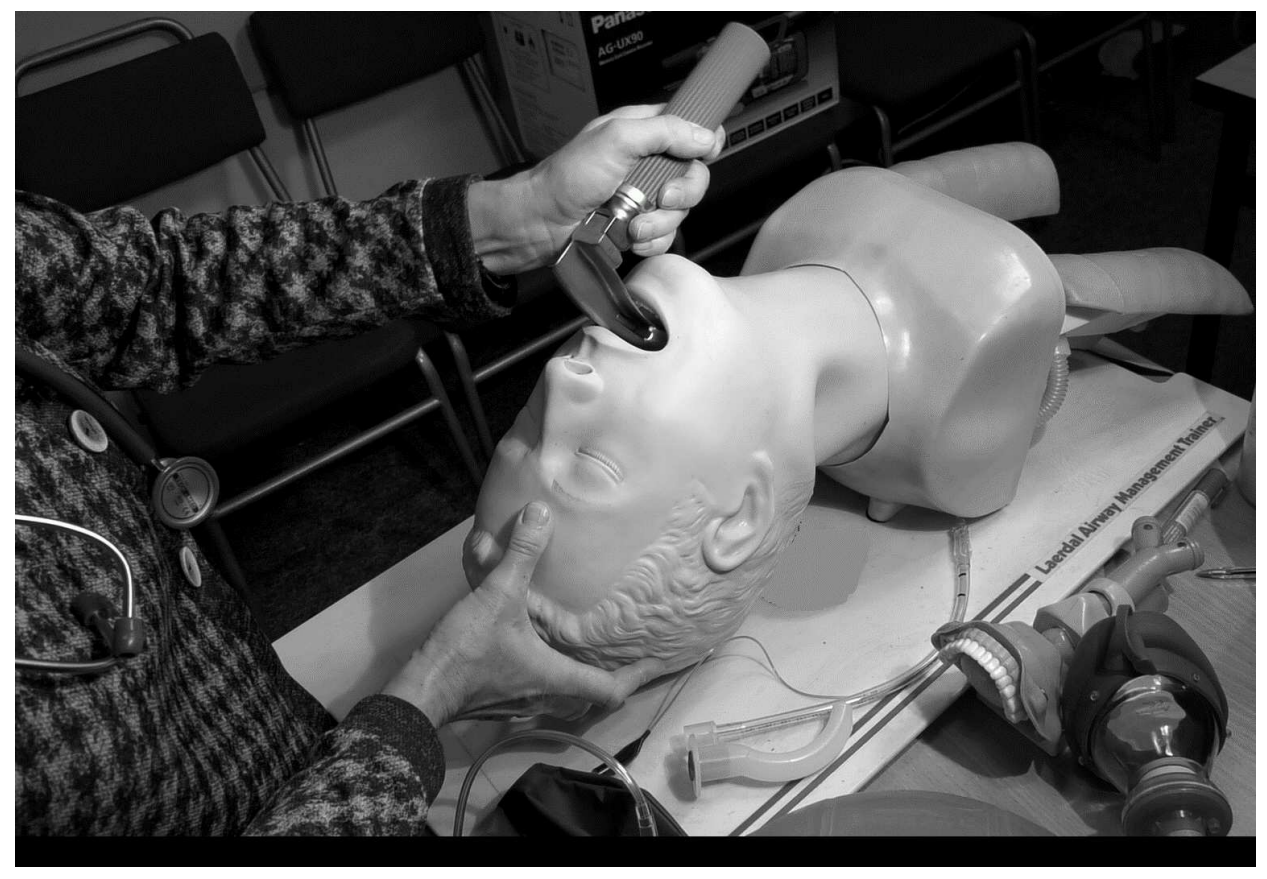

Figure 10. Recording for learning materials at the practical training classroom of the Department of Teaching Anaesthesiology and Intensive Therapy - intubation on a mannequin

In addition to the standard studio-made recordings, enriched with a presentation to discuss photos, procedures, or drawings of 'instruments', teachers may try to present these in person, so as to enhance the quality of knowledge transfer. The teachers did attempt this technique. They recorded a lecture with a live demonstration, presenting the operation of a Farrell valve pressure relief system bag. Therefore, the obvious next step was to record the practical use of the item on a mannequin in a training room. The recording studio team arrived at the Department of Teaching Anaesthesiology and Intensive Therapy to record test footage, presenting intubation on a mannequin, performed by teachers (Figure 10). To improve the outcome, a detailed script of such a recording needs to be written, some shots have to be doubled, and good lighting must be provided in the room. The teachers are already planning their work on the next demonstration recordings. This form of cooperation will certainly yield positive results in the future.

During the coronavirus epidemic, teachers have been offering their ecourses on the sOLAT education portal. Another important element has been the teacher-student communication, both individual (question asked 
to a teacher) and group communication (forum), in the asynchronous mode, where the teachers moderated the progress of e-learning meetings.

They were able to go ahead of the present situation thus providing the students with a continuity of the learning process when switching to a fully online system in March 2020.

\section{Biomechanical Examination for Physiotherapy Students}

The time of the epidemic has restricted medical students' participation in practical training included in their courses, which normally takes place in rooms equipped with specialized medical equipment. It is the case, for example, with training dedicated to Physiotherapy students performed with the use of biomechanical equipment. In these circumstances, the development of e-learning courses on the basis of study resources such as demonstration videos or instruction videos, seems to be an absolute necessity. Unfortunately, it is not possible to practice examinations in the recording studios of universities, due to the weight and dimensions of biomechanical equipment; hence, such examinations must be covered in practical training rooms.

However, with the options available in the PUMS recording studios, including the option to take the cameras off-site, teachers prepared very high quality practical video demonstrations for Physiotherapy students. The topics covered the contents taught during the individual years of study in such subjects as: Palpatory Anatomy; Special Methods in Physiotherapy; Kinesiology; or Biomechanics. The videos were produced at the Institute of Physiotherapy, or the Microsurgery and Functional Motor System Examination at the Department and Clinic of Traumatology, Orthopedics and Hand Surgery.

In the students' opinion, the educational resources thus developed constitute a significant addition to the contents discussed during synchronous meetings, e.g. on MS Teams, which is nowadays frequently used by teachers for real-time online classes. Resources developed as part of e-learning courses, where both video and audio (verbal commentary by the teacher) is important, offer a unique opportunity to play any selected multimedia materials at any time, where the learners can replay a material many times. During a synchronous meeting with time settings shared by a group, much depends on the quality of the participants' Internet connection; hence, the presented multimedia contents will often be deformed or interrupted, hindering a smooth progress of the course. E-learning resources help to minimize such issues. 
Małgorzata Grześkowiak et al.

Through a successful cooperation between teachers and a recording studio, unique learning materials could be developed in a short period of time, offering a chance for Physiotherapy students to extend their knowledge and experience, and to further develop their skills.

\section{Team Work on a Course Being Developed by Several Units in Pediatrics}

Online classes should encompass a well-designed knowledge evaluation process, including practical self-check tests for ongoing knowledge assessment by learners. In the case of clinical courses, close-ended tests, including interactive or interaction tests, are very helpful (Wejnarski et al., 2018).

An example of this concept is the e-learning course to support the refresher and practical training parts in Pediatrics for year 5 students at the faculty of Medicine, taught by teachers representing four different didactic units. All the educational resources were created during the pandemic.

The course components were adapted to the details and requirements of the actual subject courses. They included elements of asynchronous group communication (notifications, forums, schedules) as well as individual elements (questions to teachers), in addition to an important practical area in the form of tests (close-ended questions) or tasks for completion (case study or problem analysis in reply to a question/open-ended questions). The pediatrics course was a combination of open-ended questions and clinical casebased tests, in which students would record their answers to 4-6 open questions (max. 500 characters), for example: What preliminary diagnosis do you consider? What treatment will you use? Is genetic testing required, which gene(s) should be included? etc.; after finishing the test, students can see the correct answers (Figure 11). Naturally, an analysis of the answers given in such tests is worth discussing at a forum or in real time after the test is completed.

Several teachers took part in the teaching and development of the course in question, coordinated by one team member. This had a significant impact on effective course development, its contents, and moderation along the coordinator/portal administrators, coordinator/teachers and coordinator/students lines. These were the first e-learning undertakings deemed so successful by all the teachers. 


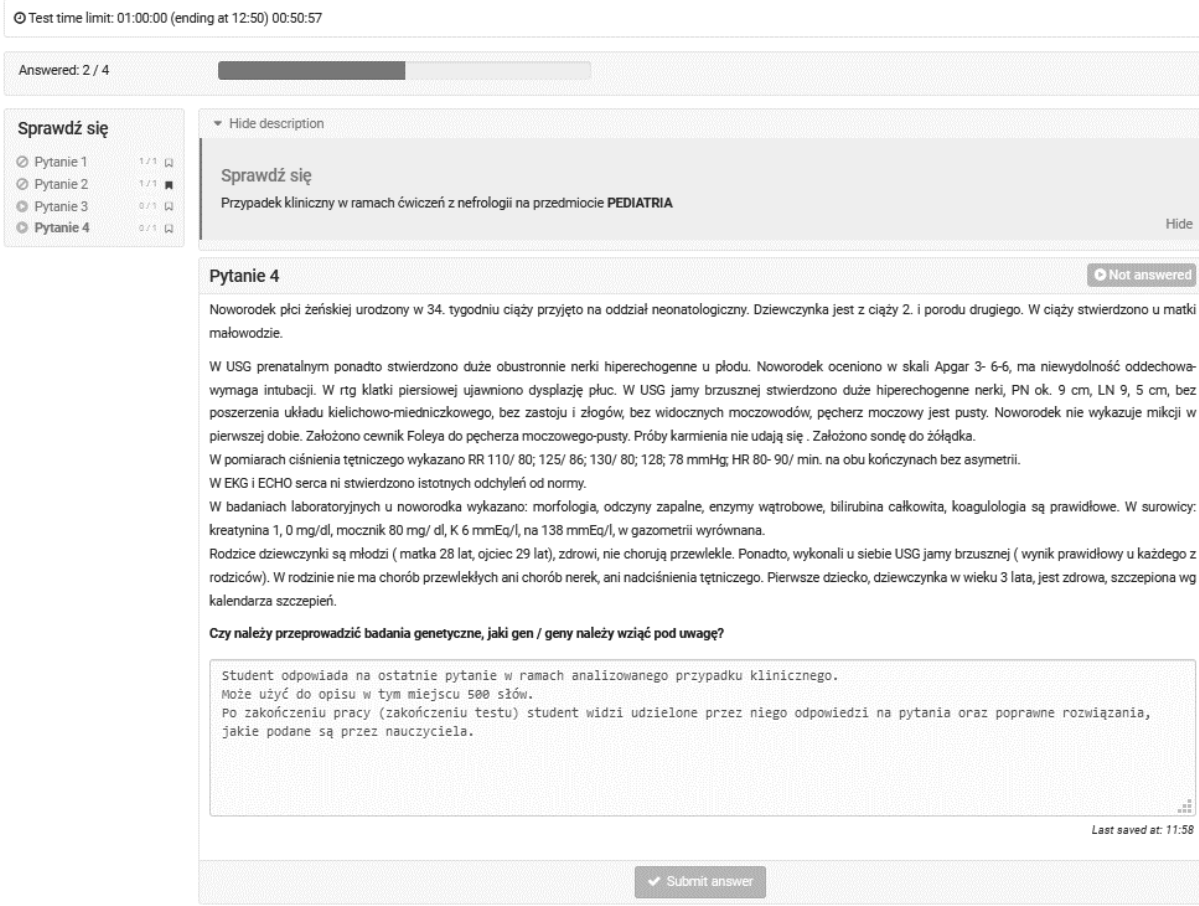

Figure 11. E-learning course in Pediatrics for year 5 students at the faculty of Medicine. Example open-ended question in a clinical case-based test

\section{Conclusion}

Distance education is a broad term that covers all knowledge transmission and evaluation methods involving the use of electronic resources, including various types of texts, graphics, audio and video materials, animations, or simulations.

Medical school students appreciate the effort teachers put in the development of e-learning resources and emphasize their usefulness. With nonstop access to online courses, they can retrieve the resources repeatedly, at any time or place. They are able to manage their schedules flexibly, according to their health status or personal circumstances. The extensive active refresher system, in forms such as self-check tests, supports creativity and prevents passive learning by memorization.

Upon measuring knowledge recipients' (course participants') competence, teachers can proceed to being active knowledge providers in an e-learning system, specifically in designing and creating educational re- 
sources. This is ensured by training programmes dedicated to the teaching staff. Moreover, ICT competences should be worked on, in combination with the development of teaching competences.

E-learning involves team work, while its efficiency largely depends on course contents; hence, the teachers are those responsible for ensuring the highest possible quality, facing a serious challenge caused by the pandemic in terms of working on resources for e-education.

\section{R E F E R E N C E S}

Boczkowska, K., Bakalarski, P., Sviatoslav, M., \& Leszczyński P. K. (2018). The importance of e-learning in professional improvement of emergency nurses. Critic Care Innov, 1(1), 16-24.

Kołodziejczak, B., \& Roszak, M. (2017). ICT competencies for academic e-learning. Preparing students for distance education - authors' proposal. International Journal of Information and Communication Technologies in Education, 6(3), $14-25$.

Kononowicz, A. A., Hege, I., Edelbring, S., Sobocan, M., Huwendiek, S., \& Durning, S. J. (2020). The need for longitudinal clinical reasoning teaching and assessment: Results of an international survey. Med Teach, Feb 4, 1-6.

Leszczyński, P., Charuta, A., Łaziuk, B., Gałązkowski, R., Wejnarski, A., Roszak, M., \& Kołodziejczak, B. (2017). Multimedia and interactivity in distance learning of resuscitation guidelines: a randomised controlled trial. Interactive Learning Environments, 1-12.

Maciejowska, I., Powierska, A., \& Krzeczkowska, M. (2019). Zastosowanie narzędzi web $2.0 \mathrm{w}$ dydaktyce akademickiej. Zeszyty Naukowe Wydziału Elektrotechniki i Automatyki Politechniki Gdańskiej, 65, 65-70.

Mokwa-Tarnowska, I. (2017). Higher interest, deeper concentration, more satisfaction - Web 2.0 tools to enhance technical English classes. In. M. Sowa, J. Krajka (Eds.) Innovations in languages for specific purposes, Innovations en langues sur objectifs spécifiques: Present challenges and future promises, défies actuels et engagements à venir. Frankfurt am Mein: Peter Lang.

Mokwa-Tarnowska, I., Kołodziejczak, B., \& Roszak, M. (2018). Od zajęć wspomaganych narzędziami internetowymi do kursów online - efektywność nowych środowisk uczenia się w opiniach studentów, Zeszyty Naukowe Wydziatu Elektrotechniki i Automatyki Politechniki Gdańskiej, 58, 57-62.

Ren-Kurc, A., Kowalewski, W., Roszak, M., \& Kołodziejczak, B. (2012). Building Digital Content for E-Learning. Information and Communication Technologies (ICT) Competence. In E. Smyrnova-Trybulska (Ed.) Monograph: E-Learning for Societal Needs (pp. 201-212). STUDIO NOA KatowiceCieszyn. 
Roszak, M. (2019). Ocena przydatności e-learningu w kształceniu medycznym z zakresu patofizjologii. Wydawnictwo Naukowe Uniwersytetu Medycznego im. Karola Marcinkowskiego w Poznaniu.

Roszak, M., \& Kołodziejczak, B. (2017). Building a course with multimedia resources -the working time analysis on the example of the pathophysiology course. Distance Learning, Simulation and Communication, 161-170.

Roszak, M., Kołodziejczak, B., Półjanowicz, W., Bręborowicz, A., Ren-Kurc, A., \& Kowalewski, W. (2015). E-learning portal tools for medical education. Studies in Logic, Grammar and Rhetoric, 43(56) Issue (2015) on Logical, Statistical and Computer Methods in Medicine, 177-193.

Roszak, M., Mokwa-Tarnowska, I., \& Kołodziejczak, B. (2019). E-learning Competencies for University and College Staff. In Universities in the Networked Society. Subtitle: Cultural Diversity and Digital Competences in Learning Communities. Series Title: Critical Studies of Education, 10, Chapter 11, Springer, 185-200.

Sobolewska, P., \& Pinet-Peralta, L. M. (2019). Use of the educational mobile applications by emergency medical services personnel. Critic Care Innov. 2(2), $25-31$.

Wejnarski, A., Gajek Villebæk, P. A., \& Leszczyński, P. K. (2018). Prospective evaluation of interactive project of Emergency Medicine Exam with the use of multimedia computer devices. Critic Care Innov, 1(1), 1-15. 